Angela Rawlings, Lara W. Hoffmann, RANDI W. STEBBINS

\title{
Multilingual Writing in Iceland The Reception of Ós Pressan and its Members Nationally and Internationally
}

\section{Introduction}

2 s Pressan is an Icelandic literary collective and small publisher founded and run by women, mostly women of foreign origin. By spring 2020, Ós had published four issues of the multilingual publication Ós - The Journal. Ós has a rather traditional nonprofit structure with a president, secretary, and treasurer all elected at the annual meeting. This structure, though, is imposed on Ós by the law in Iceland on constituting a nonprofit organization. The options were further limited by the realities around publishing a literary journal, meaning making contracts with authors, printers, suppliers, and distributors. In short, Ós Pressan needed to be an official entity here in order to meet its goals. But, that is on paper. In reality, Ós has a democratic structure. This structure and the realities of publishing and being published in Iceland are the focus of this article. We will touch on issues of gatekeeping, culturalal or national identity, and migrant literature and multilingual literature as an eruptive and disruptive force in society. We use Ós Pressan and its membership as a case study and start with a discussion about Iceland's literary landscape, where Ós is located.

The Icelandic language community is relatively small. There are about 350,000 speakers of Icelandic. A number of studies have discussed that language ideologies in Iceland are characterized by the 
notion of linguistic purism and that this approach is still a characteristic of language policies in Iceland today. ${ }^{1}$ In her assessment of language policy in the context of globalization, multicultural and international education scholar Halla B. Hólmarsdóttir asserts that "Iceland's language policy is not only a governmental policy, it is a policy that comes from the grassroots.... Icelanders are very proud of their language and are extremely determined to continually develop and preserve the language for future generations".

Despite the size og the language community, the national commitment to and interest in the Icelandic publishing industry is robust. In 2011, Reykjavík was one of the first of five cities globally to receive the status of UNESCO City of Literature, and the first city in a nonEnglish speaking country to receive the appointment (Reykjavík UNESCO City of Literature, 2020). In 2011, Iceland was the guest of honor at the Frankfurt Book Fair, with a "substantial promotional program and translation fund provided by the Icelandic project team 'Sagenhaftes Island' (Fabulous Iceland) and financial support of the Icelandic government". ${ }^{3}$ That year was also the most successful year for translations of Scandinavian literature into German, and according to Elisabeth Böker, Iceland's promotional efforts "proved so successful that other Scandinavian countries are now also eager to apply".

Icelandic literature has, for the most part, been understood as literature written by Icelanders in Icelandic. Icelandic literature is often presented as being part of a long-standing tradition going back to the Medieval Period. This notion is, for example, reinforced in the

1 See for example Hilmarsson-Dunn, Amanda, "Protectionist Language Policies in the Face of the Forces of English", The Case of Iceland. Language Policy, 5/2006, pp. 295-314. doi: 10.1007/s10993006-9027-2; Hilmarsson-Dunn, Amanda, Kristinsson, Ari Páll, "The Language Situation in Iceland", Current Issues in Language Planning, 11/2010, pp. 207-276. doi: 10.1080/ 14664208.2010.538008; Kristinsson, Ari Páll, "National Language Policy and Planning in Iceland - Aims and Institutional Activities", National Language Institutions and National Languages. Contributions to the EFNIL Conference 2017 in Mannheim, ed. Gerhard Stickel, Budapest: Research Institute for Linguistics, Hungarian Academy of Sciences, 2018, pp. 243-249.

2 Hólmarsdóttir, Halla, "Icelandic: A Lesser-Used Language in the Global Community", International Review of Education, 3-4/ 2001, pp. 379-394, https://www.jstor.org/stable/ 3445351?seq=1 [accessed April 28, 2020], here p. 391.

3 Böker, Elisabeth, "The Incredible Success Story of Scandinavian Best Sellers on the German Book Market", Scandinavian Studies, 4/2019, pp. 582-589, https://www.muse.jhu.edu/article/738251 [accessed April 29, 2020], here p. 586. Ibid. 
title of Iceland's presentation as the guest of honor at the 2011 Frankfurt book fair, Sagenhaftes Island, referring to the Icelandic sagas.

The idea of Icelandic literature as pure and homogenous prevails in the popular imagination and marketing strategies. There have been attempts at diversification, such as the inclusion of immigrant authors in Reykjavík UNESCO City of Literature ${ }^{5}$ events and a 2016 edition of Tímarit Máls og menningar that dealt directly with what it means to be an Icelandic author. ${ }^{6}$ More recently, Flóra útgáfa has included a handful of immigrant voices in its publications, such as the 2018 "Grein með hreim" essay from Jo Van Schalkwyck. Despite these initiatives, UNESCO City of Literature's website predominantly lists authors who would be classified as Icelandic ${ }^{8}$ under their authors' list, as does Flóra útgáfa? At this point, it is difficult to say if there are any long-term trends towards diversification of Icelandic literature, as was discussed in a 2020 radio program on the National Broadcasting Company's radio program titled Lestin. ${ }^{10}$ Furthermore, the Union of Icelandic Publishers has 41 members, all companies that are headed by Icelandic directors. ${ }^{11}$ The Writer's Union of Iceland has 597 members, of which only $2.5 \%$ could possibly be of foreign origin based on a quick analysis of the listed names. ${ }^{12}$

This is in stark contrast to the significant increase in the number of people living in Iceland who do not speak Icelandic as a first language in the 21st century. The number of immigrants in Iceland

5 Reykjavík UNESCO City of Literature, https://bokmenntaborgin.is/en [accessed October 16, 2020].

6 Fórlagið, TMM 3. hefti 2016 https://www.forlagid.is/baekur/timarit-mm-3-hefti-2016/?fbclid=IwAR1m7peEkqq6Ts58wiCuXsa-Ja8fnf4XM4dXyCL14E6sOueYN26b6ocjKPY [accessed October 16, 2020].

7 Van Schalkwyk, Jo "Grein með hreim”, Flóra útgáfa, 2018, https://flora-utgafa.is/2utgafa/greinmed-hreim [accessed 16.10.2020].

8 Statistics Icelandic classifies an Icelander as someone who is born in Iceland of Icelandic parents. Icelanders who have become citizens through other means are not included in this definition. Hagstofa Íslands, 2020, https://www.hagstofa.is/utgafur/lysigogn/lysigogn/?fileId=19525 [accessed October 16, 2020].

9 Flóra útgáfa, 2018, https://flora-utgafa.is/um-okkur [accessed 16.10.2020].

10 RÚV. Lestin - Íslenska með hreim, Emilíana Torrini og bókasöfn. https://www.ruv.is/utvarp/spila/ lestin/23619/7hr8me?fbclid=IwAR1iUgh6_zsOo7JqvXcJLxoELjtzgrh2J1sRo94PZY 47GOl7rnzUDsyJteA [accessed 16.10.2020].

11 Félag Íslenkra Bókaútgefenda, List of Members, 2018, https://fibut.is/english/list-of-members Laccessed April 28, 2020].

12 Rithöfundasamband Íslands. Félagatal, 2020, https://rsi.is/felagatal [accessed April 29, 2020]. 
increased from about $3 \%$ in 2000 to $14 \%$ in $2019 .{ }^{13}$ Poles, for example, comprise $40 \%$ of the total immigrant population. ${ }^{14} \mathrm{~A}$ number of studies have suggested that the language aspect is central to the inclusion of migrants in Iceland society. Unnur Dís Skaptadóttir and Pamela Innes have written that many immigrants view the difficulties they face when trying to become a member of the Icelandic speaking community, e.g. using Icelandic in their everyday lives, as "the largest hindrance to integration and acceptance". ${ }^{15}$

The imbalance in the publishing industry can also be seen in public funding for the arts. The Icelandic government directly supports writers through The Artists' Salaries, which go as well to designers, visual artists, theater groups, and others working in creative fields. In 2020, 1,410 months were awarded as artist's salaries. Of that, 555 months were awarded to writers. Six months of those 555 were awarded to a male writer of foreign origin, giving $1 \%$ in total. ${ }^{16}$ In 2019, no salary was awarded to writers of foreign origin. ${ }^{17}$ In 2018, one male writer of foreign origin received a salary for three months from the fund..$^{18}$ In 2017, a three-month salary was awarded to a female writer. ${ }^{19}$

The initiative Ós Pressan and its publication of migrant literature contributes to shifting the landscape of what is considered to be Icelandic literature. The case study of Ós Pressan focuses especially on the selection process of the work published in Ós Pressan. It also considers the role Ós has played to assist its members in starting their professional writing careers in Iceland.

13 Statistics Iceland classifies an immigrant as "a person born abroad with both parents foreign born and all grandparents foreign born". "Immigrants and Persons with Foreign Background 2019", Statistics Iceland, 2019, https://statice.is/publications/news-archive/inhabitants/immigrants-andpersons-with-foreign-background-8903 [accessed April 29, 2020].

14 Ibid.

15 Skaptadóttir, Unnur, Innes, Pamela, "Immigrant Experiences of Learning Icelandic and Connecting with the Speaking Community", Nordic Journal of Migration Research, 1/2017, pp. 20-27, here p. 25.

16 Bjarnar, Jakob, Hilmarsdóttir, Sunna Kristín, "Pessi fá listamannalaun árið 2020”, Vísir, 2020, https://www.visir.is/g/2020200109135 [accessed April 29, 2020].

17 Bjarnar, Jakob, "Pessi fá listamannalaun árið 2019", Vísir, 2020, https://www.visir.is/g/2019190119758 [accessed April 29, 2020].

18 Daðason, Kolbeinn Tumi, "Pessi fá listamannalaun árið 2018", Vísir, 2020, https://www.visir. is/g/2018180109405 [accessed April 29, 2020].

19 Olgeirsson, Birgir, "Pessi fá listamannalaun árið 2017", Vísir, 2020, https://www.visir.is/g/ 2017170109223 [accessed April 29, 2020]. 


\section{Migration, Multilingualism and Democracy in Publishing}

The author and translator Tim Parks has written about what he calls the "Dull Global Novel"20 in contemporary literature, meaning a tendency of writers to write in ways aimed at removing every obstacle to international comprehension. One example of this type of literature Parks mentions is the Japanese bestselling author Haruki Murakami. In contrast to the dull global novel, the body of research that will be discussed in this section emphasizes the use of multiple languages in literary works. While not every work of multilingual writing is at the same time migrant literature, these two genres often intersect due to language being a central aspect of immigrants' involvement in the host society. Studies on multilingual writing and migrant literature have primarily been conducted in larger language communities with longer histories of immigration, as the examples discussed here demonstrate.

Albert Rossisch has described that literature that uses more than one language breaks with the idea of monolithic concepts such as "French Literature" or "Italian Literature." Rossisch emphasizes the "the radical anomaly of certain texts - those which use more than one language - that simply cannot be fitted into a specific tradition because they voluntarily straddle two or more literatures." ${ }^{21}$ Even though Rossisch does not mention Icelandic literature, the idea of multilingual literature as a way of breaking with literary traditions is particularly relevant when considering the close links between national identity and the Icelandic language.

Yasemin Yildiz ${ }^{22}$ offers a similar perspective and suggests that the field of literary studies should go beyond the monolingual paradigm, which she sees as the dominant perspective of scholars of literature until recent years. Yildiz discusses a number of examples from postmonolingual German literature using more than one language. She

20 Parks, Tim, "The Dull Global Novel”, Where I'm Reading From: The Changing World of Books, Tim Parks, New York: New York Review Books, 2015, pp. 25-28, here p. 25.

21 Rossich, Albert, “An Overview of Literary Multilingualism”, Comparative Critical Studies, 1/2018, pp. 47-67, doi: 10.3366/ccs.2018.0259, here p. 50.

22 Yildiz, Yazemin, Beyond the Mothertongue. The Postmonoligual Condition, New York: Fordham University Press, 2012. 
shows how writers such as Yoko Tawada, Emine Sevgi Özdamar, and Feridun Zaimoğlu write across various languages and rethink and reinvent the category of the mother language. Yildiz's definition of the postmonolingual condition thereby encompasses writing in one language that shows influences from multiple languages, such as the work of Franz Kafka. Yildiz emphasizes Kafka's upbringing in a multilingual environment in Prague. Due to the strong connections between language and identity, multilingual literature can, therefore, show complex identities in ways that literature aimed at being understood by as many readers as possible cannot.

The research discussed above emphasizes how multilingual writing can reflect (migrant) identities and societal change. There is also an increasing number of studies coming from the social sciences that empirically investigate the impact of art and literature on migrants' lived experiences. Jeffery, Palladino et al. provide a thorough overview of this field of research. ${ }^{23}$ Damery and Mescoly argue that "art offers opportunities for migrants to actively participate in the sociocultural and political environment in which they reside and to claim various forms of official and unofficial belonging whether it occurs through visibility or invisibility". ${ }^{24}$ Otte states that artistic projects can lead to bonding and bridging between different groups,${ }^{25}$ hereby referring to Robert D. Putman's well-known distinction between two types of social capital, bonding and bridging. ${ }^{26}$ In the case of Iceland, the notion of bonding and bridging between different communities is relevant as a 2020 report by Unnur Dís Skaptadóttir and Kristin Loftsdóttir found that foreign women perceived that they were primarily asked for their opinion on so-called immigrants, instead of being involved in discussions about a broad range of issues in Icelandic society. ${ }^{27}$

23 Jeffery, Laura, Palladino, Mariangela, Rotter, Rebecca, Woolley, Agnes, "Creative Engagement with Migration”, Crossings: Journal of Migration E Culture, 10/2019, pp. 3-17. doi: 10.1386/cjmc.10.1.3_1.

24 Damery, Shannon, Mescoli, Elsa, "Harnessing Visibility and Invisibility through Arts Practices: Ethnographic Case Studies with Migrant Performers in Belgium”, Arts, 8/2019, pp. 1-17. doi: 10.3390/arts8020049, here p.1.

25 Otte, Hanka, "Bonding or Bridging? On Art Participation and Social Cohesion in a Rural Region of the Netherlands", Poetics, 2019, doi: 10.1016/j.poetic.2019.02.006.

26 Putnam, Robert, Bowling Alone: The Collapse and Revival of American Community, New York: Simon \& Schuster, 2000.

27 Skaptadóttir, Unnur Dís, Loftsdóttir, Kristín, Konur af Erlendum Uppruna. Hvað Kreppir að?? Skýrsla unnin fyrir félagsmálaráđuneytið, Reykjavík: Háskóli Íslands, 2020, here p. 55. 
While the aforementioned studies show a positive link between artistic projects and migrants' involvement in the host society, intention and outcome of artistic projects aimed at migrants are not always aligned. Claire Bishop has emphasized that just calling artwork participatory does not mean that participation has necessarily occurred. ${ }^{28}$ The Rise Manifesto, written by refugees and asylum seekers in Australia, is aimed at artists wanting to work with refugees or asylum seekers. Their statements can be transferred to other groups of migrants and vulnerable groups as well. One of their statements is that "[i]t's not a safe space just because you say it is", emphasizing that the groups targeted by specific projects are the ones who should have a say in whether a project has reached its aim of being, for example, inclusive or safe for vulnerable groups. ${ }^{29}$

The structures behind participatory and co-produced works of art or literature, are, therefore, important to consider. Dewey's ${ }^{30}$ idea is of participatory democracy as a social way of being that requires informed and open communication. In it, he included "liberation of powers" and "widening the area of shared concerns." Dewey argues that democracy is not an abstract. Instead, democracy takes place in a community, one that is always in the making. ${ }^{31}$ It could be said, though, that democracy takes place in multiple communities inside a wider society and access, often controlled by gatekeepers, to those communities is not equal.

Informed and open communication is the antithesis of gatekeeping. It was perhaps Dorothy Smith ${ }^{32}$ who first talked of gatekeepers in academia, people and organizations that set standards of taste and knowledge and monitor who gets accepted into the systems they keep. Dale Spender built on Smith's observations to talk about the

28 Bishop, Claire, Artificial Hells: Participatory Art and the Politics of Spectatorship, London: Verso, 2012.

29 Rise, "10 things you need to consider if you are an artist not of the refugee and asylum seek-er community looking to work with our community", Rise, Refugees, Survivors and Ex-detainees, http://riserefugee.org/10-things-you-need-to-consider-if-you-are-an-artist-not-of-the-refugeeand-asylum-seeker-community-looking-to-work-with-our-community [accessed April 30, 2020 ].

30 Dewey, John, Democracy and Education, Holywood, FL: Simon \& Brown, 2012 [1916].

31 See Greene, Maxine, "Diversity and Inclusion: Toward a Curriculum for Human Beings", Teachers College Record, 2/1995, pp. 211-221.

32 See Smith, Dorothy, “A Peculiar Eclipsing: Women's Exclusion from Man's Culture”, Women's Studies International Quarterly, 4/1978, pp. 281-296. 
work of gatekeepers in academic publishing. ${ }^{33}$ She named editors, publishers, reviewers, and referees as those in gatekeeping positions. Since Spender's work came, much research has been done on gatekeepers in academic publishing. In the wider field of publishing, the debate rages about the necessity vs. evil (maybe necessary evil) of publishing gatekeepers. ${ }^{34}$

For a broader perspective, the American organization VIDA: Women in Literary Arts conducts an annual count of gender representation in almost forty literary journals and periodicals. ${ }^{35}$ Volunteers across the USA "dedicate thousands of combined hours to perform [this] arduous task: we manually, painstakingly tally the gender disparity in major literary publications and book reviews." With the initial results in 2010 obviating that men are published with much greater frequency, this accounting promulgated nationwide conversation that has since "affected change in the publishing industry, [and] has also created a strong community of writers and advocates." Following VIDA's lead, Canadian Women in Literary Arts (CWILA) was formed in 2011 to conduct a count of gender representation in Canadian literary publications, and to "share feminist values and see the importance of strong and active female perspectives and presences within the Canadian literary landscape." The advocacy work of both VIDA and CWILA offer solid examples of volunteer collectives whose aims intend to support underrepresented populations through enabling discussion and action of current gatekeeping within literary scenes.

Migrant literature, multilingual writing and democracy are, therefore, aspects that reflect and influence the inclusion of migrants in receiving societies and challenges literary traditions. Ós Pressan was, and still is, the only nonprofit in Iceland dealing directly with intersectional issues of marginalization in literature and the literary field in the country. The idea of Icelandic literature as pure and ho-

33 See Spender, Dale, "The Gatekeepers: A Feminist Critique of Academic Publishing", Doing Feminist Research, ed. Helen Roberts, London: Routledge, 1981, pp. 186-202.

34 Some, such as William Marlen (2016), have looked at how gatekeeper agency can lead to wider representation, particularly around the emergence of world literature. See William Marling Gatekeepers: The Emergence of World Literature and the 1960s, Oxford: Oxford University Press, 2016, doi: 10.1093/acprof:oso/9780190274146.001.0001.

35 VIDA: Women in Literary Arts. About the VIDA Count, https://www.vidaweb.org/the-count [accessed April 28, 2020]. 
mogenous prevails in the popular imagination and marketing strategies. This leads us to ask how an initiative such as Ós Pressan and its multilingual publishing concept, can contribute to shifting the landscape of what is considered to be Icelandic literature.

\section{Context: Short History of Ós}

As Sara Ahmed wrote, "[w]hen you expose a problem you pose a problem. It might then be assumed that the problem would go away if you would just stop talking about it or if you went away." ${ }^{6}$ Exposing the problem with publishing in Iceland is exactly what Ós started out to do and continues doing. The nine women, all immigrants to Iceland but one, who started Ós in 2015 met in literary workshops facilitated by angela rawlings, herself an immigrant, in 2014 and 2015. During those workshops, they and several others began to talk about who has the right to be called a writer in Iceland and who is represented in the publishing industry. As Angela tried to find a publisher for a book showcasing the writers of the workshop, the barriers to publishing in Iceland became more than just rumors. Her book proposal came from work with multilingual writing in Reykjavík, but it was turned down by Icelandic publishers. This mirrored the experiences of other, non-Icelandic authors trying to get published in the country. At one point, the participants joked that it would be easier to have the book published abroad, translated, and imported to Iceland. In the spring of 2015, as the workshop drew to a close, a few participants switched from joking to seriously considering the possibility of creating printed, online, and physical spaces for marginalized authors.

The workshop had been supported by Reykjavík UNESCO City of Literature, as was the budding writing and publishing collective. Ós members' first performances were at Reykjavík Culture Night in August 2015 under the banner of UNESCO and the first exhibit welcoming the new nonprofit was in October 2015 at the downtown branch of the Reykjavík City Library. By December 2015, Ós had put out its first call for submissions for the first edition of its literary

36 Ahmed, Sarah, Living a Feminist Life, Durham: Duke University Press, 2017, here p. 37. 
journal. Mindful of the gatekeeping practices around literature in Iceland, the strongest restriction in the call was a limit of five, A4 pages per submitter. Even this was put in to ensure the broadest number of voices in the first journal.

Authors are otherwise not limited by genre, language, format, or theme. Even their connection to Iceland was phrased as needing to be "on, about, or otherwise connected to" the island. Ós Pressan has, over the years, also started to organize activities outside of the capital area, meaning Reykjavík and its surrounding municipalities. This started with a reshowing of the exhibit This is $O_{s} /$ Detta er $U_{s}$, which had originally been in the Reykjavík City Library, at the central library in Akureyri, the largest town in the north of Iceland. In 2018, one of the members moved to Akureyri and has since then organized several events there. In 2020, Ós Pressan received a grant from the city of Akureyri to organize a series of writers' workshops there. In 2020, another member of Ós Pressan spent several months in the village of Pingeyri in the Westfjords at a writer's residency. Members going to other parts of Iceland have extended the nonprofit's presence, but the bulk of the publishing happens in Reykjavík.

By spring 2020, Ós Pressan had published four issues of its annual journal and held a number of workshops and readings. The first journal featured six languages, the second eight had eight, the third had five, and the fourth had eleven. Os - The Journal is an example of migrant literature and multilingual literature of which the following section provides an overview.

\section{Methodology and Positionality}

Ós Pressan is presented as a unique case study in a country where the bulk of immigration and diversifying demographics has occurred largely in the 21st century, rendering it non-comparable to literary landscapes in other Nordic or European countries. Moreover, single case studies have an important and long-standing tradition in the social sciences. ${ }^{37}$ Though there is a trend for cross-case analysis, that 37 Blatter, Joachim and Markus Haverland, "Relevance and Refinements of Case Studies", Designing
Case Studies, Berlin: Springer, pp. 1-32, doi: 10.1057/9781137016669_1 
does not detract from the history and usefulness of single case studies, especially of new or relatively unique phenomenon. While this may be considered a limitation of this study, it is a limitation that has been noted, but is not fatal, in case study methodology as a whole.

Ós was chosen since it was, and still is, the only nonprofit in Iceland dealing directly with intersectional issues of marginalization in literature and the literary field in the country. As Yin pointed out, case studies are useful for understanding broader social and political phenomena, such as is done here. ${ }^{38}$ We focus primarily on the selection process of pieces for Ós - The Journal and the case of members of Ós Pressan starting a career in publishing. We further evaluate media reception of Ós Pressan in Iceland and abroad as external markers for the case study's presence.

Analysing media representations can be a useful tool for better understanding how intergroup relationships are built or continued. ${ }^{39}$ Media analysis, however, needs to connect specific text with a specific context. ${ }^{40}$ In this paper, the media is used to better understand the context of literature in Iceland and how Ós Pressan and its members have been received. The media analyzed includes both printed and online newspapers and radio broadcasts.

Looking at the media also balances the fact that all three authors of this paper are Ós insiders. Two of the researchers have been members of Ós Pressan since its inception and the third scholar joined a year later. This position surely has an impact, since as Denzin pointed out, research "begins and ends with the biography and self of the researcher." 41

Our case study is based on our personal experiences, the full documentation available to us as insiders and the public record of Ós and its members found in the media, social media, and organizational (both of Ós and others) webpages. Our situated knowledge ${ }^{42}$ is

38 Yin, Robert K., Case Study Research Design and Methods, Thousand Oaks, CA: Sage, 2014 [1984].

39 Hodgetts, Darrin and Kerry Chamberlain, "Analysing News Media", The SAGE Handbook of Qualitative Data Analysis, pp. 380-393. London: SAGE Publications Ltd, 2014. doi: $10.4135 / 9781446282243$.

40 Ibid.

41 Denzin, Norman. K, The Research Act: A Theoretical Introduction to Sociological Methods, Upper Saddle River, NJ: Prentice Hall, 1989, here p. 12.

42 Haraway, Donna, "Situated Knowledges: The Science Question in Feminism and the Privilege of Partial Perspective”, Feminist Studies, 3/1988, pp. 575-599. doi:10.2307/3178066. 
informed by us being involved in the publishing initiative. This means that we are aware of the intentions behind Ós Pressan.

For example, an outsider researcher might be able to reflect on the projects that Ós Pressan has done in communities in Iceland, but might not necessarily know about the projects that Ós Pressan did not manage to complete and the communities that we have not been able to reach. As insiders, we know which grant proposals have been successful, but we also know about applications that have not succeeded. Being insiders provides valuable information about the realities of a multilingual publishing initiative in Iceland and both the challenges and positive reception of Ós Pressan as a non-profit organization based on volunteer work in the past years. As Ós Pressan is a democratic initiative, this article has also been written collaboratively by three researchers and reflects our different perspectives on Ós Pressan and its meaning in the Icelandic literary landscape.

The democratic core can be demonstrated by the approach used by Ós Pressan to select pieces for publication, which will be discussed in the following section.

\section{Democracy in action: Selecting pieces for publication}

Selecting pieces for publication is a gatekeeping activity. That cannot be denied. Even when gatekeeping, Ós attempts to be as open as possible and not use language as the primary determining factor for inclusion in the journal. Between nine and eleven people sit on the editorial board, and each has a vote about which pieces to include in the journal, even if their vote is to abstain from voting. Each member of the editorial board has access to several languages and backgrounds in several genres. If a language or genre is unknown to the board members, they find outside reviewers for the pieces. This happened in the second journal, when someone submitted in Kurdish. From the short description of the piece in English that came from the author, the board was sure that they wanted to print it, but they needed confirmation that the Kurdish matched the English. After the votes are recorded, the editorial board meets for a discussion of 
the pieces with mixed reactions. These are always lively and interesting.

When selecting pieces for Ós The Journal No. 3, a new issue presented itself. After much deliberation when forming Ós, the members had decided on a printed, black-and-white literary journal. Suddenly, the editorial board was enchanted by a number of submissions of visual poetry, comic strips, visuals with poetry, and other visual material. Knowing that printing in color was outside the budget and did not fit well with the journal's format, the board was facing having to exclude these innovative pieces. Instead of giving up, the board decided to combine an online and printed edition of the journal. The visual pieces would be assigned $\mathrm{QR}$ codes that would lead to protected, online versions of the full-color piece. Each author would be credited with the printed code and some of the pieces were printed in part in the journal. The board, however, did not go ahead with this plan without first talking to each author of the accepted visual pieces and getting their approval for the hybrid publication of their work.

Ós strives to find creative and open ways of inviting submissions, deciding on submissions, and publishing pieces that might otherwise be seen as unpublishable. In Ós The Journal No. 4, we included sound pieces using the same $\mathrm{QR}$ code technology.

\section{Reception of Ós Pressan in Iceland and Abroad}

Since its inception in 2015, Ós Pressan has been active in Reykjavík, in Iceland, and abroad. The list below is taken from Ós' annual reports and its publication list.

- 32 national and 1 international readings, including the launch of 4 editions of the journal

- 16 workshops

- 8 publications

- 5 exhibitions

- 3 literary collaborations locally and 1 internationally

- 5 national and international lectures

- 1 successful grant from the Icelandic Equality Fund 
- 1 successful crowdfunding campaign through Karolína Fund

- 1 successful grant from the City of Akureyri Culture Fund

- Articles on Ós in all major newspapers, twice in the Englishlanguage publication of Grapevine

- Ós members asked to contribute to international blog on multilingual writing

- Appeared 4 times on Orð um bækur, a weekly radio roundup of what is happening in the literary scene in Iceland and abroad

- Members invited to read and speak at Reykjavík UNESCO City of Literature events, including the month of Reykjavík Reads in October every year.

Many of the events have been attended by both immigrant and native Icelandic authors, musicians, and artists. Some of them, along with Ós and its members, have received media coverage.

\section{Reception in the Media}

When looking at the media coverage, themes emerge both nationally and internationally. Interestingly, these themes vary somewhat between the national and international levels. We can further observe some differences between media reports by Icelandic-speaking media and media reports by English-speaking media. Overwhelmingly, the press and reaction to Ós and its activities has been positive here and abroad, but the international press coverage tends to focus more on the organization's novel structure, language policy, and publications while the local media takes a more othering tone. ${ }^{43}$

Ós has been featured in both English- and Icelandic-language media in Iceland. In both languages, the interviewers have focused on the language of the publication and their perceptions of the difficulties of finding an audience in Iceland. The articles have used phrasing such as "Vettvangur fyrir skáld sem skrifa á ólíkum tungumálum" (a

43 Allen, Stuart, "Journalism and the Culture of Othering”, Brazilian Journalism Research, 2/2010, doi: 10.25200/BJR.v10n2.2014.776. 
forum for poets who write in different languages). ${ }^{44}$ This indicates a tendency towards othering the group and keeping languages other than Icelandic outside mainstream publishing in Iceland.

On the whole, media based in Iceland focuses more on the organizational structure of Ós Pressan and what is novel about this initiative in Icelandic publishing, e.g. emphasizing the use of multiple languages ("fjölmála samfélag rithöfunda"), ${ }^{45}$ and the fact that most of the members of Ós Pressan are of foreign origin. The articles do not engage with the writing published by Ós Pressan or the individual members of Ós Pressan. When referring to individual members who are authors, articles have tended to emphasize their countries of origin and how long they have lived in Iceland. One example of this can be found in an article published in Vísir in 2015:

\begin{abstract}
"Par lesa tvær skáldkonur upp, pær Ewa Marcinek frá Póllandi sem hefur búið á Íslandi í tvö ár og hin bandaríska Randi Stebbins sem flutti til Íslands á síðasta ári” ‘́6 (two authors will be reading there, Ewa Marcinek from Poland, who has been living in Iceland for two years, and the USAmerican Randi Stebbins who moved to Iceland last year).
\end{abstract}

Four years later, the following September 2019 example is indicative of a continued emphasis in Icelandic media on local writers' countries of origin.

"Hér má heyra í litháíska ljóðskáldinu Mantas Balakauskas, sagnakonunum Ewu Marcinek frá Póllandi og Helen Cova frá Kolubíu [sic] sem báđar hafa verið búsettar á Íslandi um nokkurt skeið”47 (Here you can hear the Lithuanian poet Mantas Balakauskas and the storytellers Ewa Marcinek from Poland and Helen Cova from Colombia who both have been living in Iceland for a while).

\footnotetext{
44 Guðjónsson, Kristján, "Fjölmála skáldasamfélag", 2016, https://www.dv.is/fokus/menning/ 2016/05/07/fjolmala-skaldasamfelag [accessed 30.04.2020].

45 Ibid.

46 Gunnarsdóttir, Gunnpóra, "Nýjar Raddir Skálda”, Vísir, 2015, https://www.visir.is/g/ 2015707259997 [accessed 30.04.2020].

47 Sigurðardóttir, Jórunn, “Ljóð og sögur á ólíkum tungumálum”, RÚV, 2019, https://www.ruv.is/ frett/ljod-og-sogur-a-olikum-tungumalum [accessed April 30, 2020].
} 
Besides the focus on the authors' countries of origin in this example, it is noteworthy that Cova, whose work is discussed in more detail later in the article, is originally from Venezuela, not Colombia.

Interestingly, in articles published in English-speaking media in Iceland, the countries of origin and length of stay of the members of Ós Pressan were not mentioned and discussed. Still, the focus of the articles published in English-speaking newspapers was on the structure of Ós Pressan and on multilingual publishing. Ós Pressan is not being discussed as a part of Icelandic literature.

The contrast between national and international reception of the new writing collective can be exemplified by an in-depth interview by Clarise Foster with Ós member in CV2 - The Canadian Journal of Poetry and Critical Writing ${ }^{48}$ in their special edition on Icelandic - Canadian poets and writing. The interview questions range from delving into the history of Ós and its founders to covering the diversity of the group and its democratic practices. In one question, Foster asks about "the degree of marginalization from the established literary scene" ${ }^{3 / 9}$ foreign-born authors experience in Iceland. Foster then probes deeper in the following question about the established literary scene in Iceland and its role in marginalizing some authors.

Later, the interview turns to Ós' model of governance and selecting pieces for publication. There, the question asks how "the differences in cultural orientations/experiences come together" 50 to form a functioning governance group for Ós. The interview also includes questions on Ós' “'literary' mandate” and publication criteria ${ }^{51}$. Importantly, the journal printed the answers from Ós and its members in full, meaning that the diversity of voices that is Ós was preserved as much as possible.

A similar willingness to engage with Ós' critique of Icelandic publishing traditions can be seen in an article on Icelandic literature and language from 2018. Published in Airbnb Magazine, the article focuses on Icelandic fears of language loss and on language preserva-

48 Foster, Clarise, "An Interview with Ós Pressan Collective Members: a rawlings, Randy Stebbins, Anna Valdís Kró, Beatriz Portugal, Ewa Marcinek, Virginia Gillard and Elena Ilkova”. CV2: The Canadian Journal of Poetry and Critical Writing, 40/2017, pp. 21-35.

49 Ibid, p. 25.

$50 \quad$ Ibid, p. 33.

$51 \quad$ Ibid, p. 32. 
tion in literature. Ós is used as a counterpoint to the dominant narratives on these two important issues by focusing on the struggle that foreign-born writers face and how language is weaponized in that struggle. ${ }^{52}$

A third example of international coverage that is more open to Ós and its members voicing critiques of the Icelandic publishing sector came from an invitation from Finland in 2018 for Ós to be part of Multilingual Month. ${ }^{53}$ In this case, two Ós members were commissioned to write a blog post about their experiences in publishing a multilingual literary journal in Iceland. The fact that Ós Pressan was paid for this contribution is an acknowledgement of the status of Ós Pressan in the context of discussions about multilingualism in the Nordic countries and the positive reception of Ós Pressan abroad. In the post, two Ós members describe their experiences starting and joining the group and at a Nordic multilingual conference. In the post, they cover issues of radical inclusion, playful multilingualism, and marginalization in literature, all without editing or comment by the organizers of Multilingual Month.

\section{Public Reception of Foreign-Origin Writers}

Foreign-origin authors who immigrated to Iceland after their literary careers were established overseas (such as angela rawlings, Elías Portela, or Mazen Maarouf) have continued to situate their publishing activities in international contexts, in part due to the limited publishing opportunities available to foreign-origin authors in Iceland. There are notable inclusions over the years-through the previously mentioned Listamannalaun, through invitations to participate in local literary events, and through selective invitation to contribute to Icelandic literary journals Tímarít Máls og menningar and Stína. Still, the public acknowledgement of international publishing activities by foreign-origin authors remains limited - even when new books are

52 Griest, Stephanie Elizondo, “The Quest to Keep Iceland's Language Alive”, airbnbmagazine, 2018, https://medium.com/airbnbmag/the-quest-to-keep-icelands-language-alive-b22d4b6d74f2 [accessed April 30, 2020].

53 Valdis Kro, Anna, Hoffmann, Lara, “Ós Pressan”, Multilingual Month, 2019, https://multilingualmonth.org/2019/03/18/os-pressan-2/ [accessed April 28, 2020]. 
published or nominations for major awards arise, as was the case when Maarouf's Jokes for the Gunmen was nominated for the 2019 Man Booker International Prize.

To launch one's literary career in Iceland as a foreign-origin author is new territory for which Ós Pressan has been both witness and support. Ós members Ewa Marcinek and Helen Cova have opted over the past few years to initiate their first publications within Iceland. Their examples are indicative of the non-conventional paths that foreignorigin authors devise in order to participate in the Icelandic publishing industry and circulate within the national arts scene. The public reception to Cova's and Marcinek's written and staged literary output can be analyzed through event attendance, sales figures, and media coverage.

Autofiction author Ewa Marcinek originates from Poland, where she completed a BA in Creative Writing and an MA in Culture Studies at the University of Wrocław prior to immigrating to Iceland. From 2015 to now, Marcinek has developed a multilingual (English, Icelandic, and Polish) collection of short stories and poetry entitled Polishing Iceland based on her personal experience as a Polish woman living in Iceland. An excerpt from her manuscript was translated into Icelandic by Helga Soffía Einarsdóttir for Sjón's guest-edited issue of Tímarít Máls og menningar. ${ }^{54}$ The issue focused on addressing the question "What is an Icelandic writer?" partly through inclusion of foreign-origin texts in translation.

Since 2017, Marcinek has been invited to read her work at numerous literary events, particularly those with an emphasis on multiculturalism such as Reykjavík City Hall's Lesum heiminn / Read the World. ${ }^{55}$ In 2018, Marcinek consulted for The National Theatre of Iceland on written and spoken Polish language included in their production Svartalogn. ${ }^{56}$ Her theatre contribution led to director Pálína Jónsdóttir inviting Marcinek to join her in the founding of Reykjavík International Theatre Company in 2019. Before the year finished, the company adapted fiction by Marcinek, Mazen Maarouf, and Elías

54 Marcinek, Ewa, “Ísland pólerað”, Timarít Máls og Menningar, 2016.

55 "Lesum Heiminn / Read the World”, Bókmenntaborgin, 2018, https://bokmenntaborgin.is/lesumheiminn [accessed 28 April 2020].

56 "Svartalogn“, pjóðleikhúsið, 2018, https://www.leikhusid.is/syningar/svartalogn [accessed April $28,2020]$. 
Portela for their inaugural performance Opening Ceremony. Their second adaption focused solely on Marcinek's in-progress manuscript, premiering Polishing Iceland at independent theatre Tjarnarbíó for 150 guests in 2020.

Media response to Marcinek's work has been abundant, frequently foregrounding her identity as a foreign-origin author in keeping with her autofiction subject matter. RÚV journalist Jórunn Sigurðardóttir offered a succinct biography of Marcinek in an article on Icelandic literature and translation (Sigurðardóttir, 2018); the article emphasized Marcinek's heritage in the context of Soviet-era Poland. The Reykjavik Grapevine titled their 2020 interview with Marcinek and Jónsdóttir "The Reykjavík Ensemble Brings The Polish Experience To The Stage" ${ }^{57}$ Jakob S. Jónsson's review of Polishing Iceland in Kjarninn further emphasized that stage adaption of Marcinek's work indicates "a world that all immigrants... are familiar with and, fortunately, more and more Icelanders are also beginning to recognize". 58 He went on to write that Marcinek's co-founded theatre company Reykjavík Ensemble "is tangible evidence that Iceland is moving closer to becoming a part of the universe and to Iceland being part of the world's humanity."

Children's author and short-story writer Helen Cova is originally from Venezuela. She published her first children's book in 2019 with the Icelandic publisher Bjartsýn. While the partnership with Bjartsýn enabled distribution for the book, Cova was responsible for providing the full cost of printing - rendering the publishing process closer to self-publishing than acquisition by an independent publishing house. Under the auspices of Bjartsýn, Cova printed her children's book as three hardbound editions in three languages: Snúlla finnst gott à vera einn (Icelandic), Snulli likes being alone (English), and A Snúlli Le Gusta estar solo (Spanish). The book was co-illustrated with 9-year-old Icelandic boy Davío Stefánsson. By offering her book in three languages,

57 Beckett, Rex, "Polishing Iceland: The Reykjavík Ensemble Brings The Polish Experience To The Stage", The Reykjavík Grapevine, 2020, https://grapevine.is/icelandic-culture/2020/03/09/polishing-iceland-the-reykjavik-ensemble-brings-the-polish-experience-to-the-stage [accessed 28 April, 2020].

58 Jónsson, Jakob S., "Kvenleg reynsla, ósvikin kómík. Leiklistargagnrýnandi Kjarnans fjallar um sýningu Reykjavik Ensemble, Polishing Iceland”, Kjarninn, 2020, https://kjarninn.is/folk/202003-20-kvenleg-reynsla-osvikin-komik [accessed 30 April, 2020]. 
Cova asserted the significance of multilingualism and immigrant outreach within her foray into the Icelandic publishing scene. Cova confirmed that, as of April 2020, she has distributed 305 Icelandiclanguage, 71 English-language, and 46 Spanish-language copies within Iceland. ${ }^{59}$

Cova sought to partner with an Icelandic publisher, though funding the publication herself as a means to ensure her children's book would be published in three languages and disseminated within the Icelandic market. After self-funding the project, Cova has now recuperated the printing costs through book sales. After the books' launch, Cova received invitations to read at literary events organized by the Akureyri library Amtsbókasafnið (Akureyrarbær, 2019) and Reykjavík UNESCO City of Literature. ${ }^{60}$ She also participated in a radio interview via the national broadcaster's program KrakkaRÚV. ${ }^{61}$ Iceland's national broadcaster, RÚV, also interviewed Bjartsýn's publisher Sunna Guðnadóttir about Cova's book. ${ }^{62}$ It is notable that Cova herself was not interviewed, but rather the publisher spoke in Icelandic about the book's content and resonance with young readers. The choice of Icelandic media to interview the publisher, rather than the author, of a new book is non-standard. The interview, though, led with a photo of Cova next to her books.

Through their self-initiated forays into the Icelandic literary industry, both Marcinek and Cova have been invited to participate in numerous events emphasizing multiculturalism in the arts. In 2019, Cova and Marcinek read at a literary translation event organized by Reykjavík City Library. ${ }^{63}$ The following year, Reykjavík City Library again invited Cova and Marcinek to collaborate on an inclusive public spaces project. ${ }^{64}$ Cova was further invited by the Menningarhús (Cul-

59 Cova, Helen, 2020, personal communication, April 8-9.

60 "Lesum Heiminn / Read the World", Bókmenntaborgin, 2018, https://bokmenntaborgin.is/lesumheiminn [accessed 28 April 2020].

61 “Sögur - Snúlla finnst gott að vera einn”, Útvarp KrakkaRÚV, 2019, https://player.fm/series/ utvarp-krakkaruv/sogur-snulla-finnst-gott-ad-vera-einn [accessed April 28, 2020].

62 Einarsdóttir, Júlía Margrét, "Skrímsli kennir börnum kosti einverunnar", RÚV, 2019, https:// www.ruv.is/frett/skrimsli-kennir-bornum-kosti-einverunnar [accessed April 28, 2020].

63 "Lesum Heiminn / Read the World", Bókmenntaborgin, 2018, https://bokmenntaborgin.is/lesumheiminn [accessed 28 April 2020].

64 “Cultural Narratives”, Borgarbókasafnið, 2020, https://borgarbokasafn.is/event/welcome/postponed-cultural-narratives [accessed April 28]. 
tural House) department of the City Library to participate in a foreign artists project where she will facilitate cultural activities for children and families. Marcinek has likewise created workshops to support fellow writers, focused on podcast production and creative writing for Polish women in Iceland.

Without opportunities in Iceland's official publishing industry, foreign-origin authors are more likely to seek self-publishing opportunities or international contracts. This places the writers in precarious situations where they are less likely to be financially supported by the communities in which they contribute and subjected to local isolation from the larger national literary context. Cova, for example, will self-publish her second book in 2020 - a collection of short stories for adult readers. The trailblazing of foreign-origin authors, though, does contribute to the diversification of Iceland's publishing industry.

\section{Discussion and conclusion}

Ós stepped into the publishing world of Iceland in order to allow as many voices as possible to participate in literature. In a country that rightly prides itself on its literary past and present, participating in literature production that is a way of claiming social space, printed, virtual, and physical, for immigrants and other marginalized people. In order to do this, Ós publishes multilingual literature, which, as has been discussed in this paper, breaks with traditional ideas of what is Icelandic literature and, therefore, with monolithic concepts of national literature. ${ }^{65}$

Ós makes a public record of their thoughts through writing and other creative pursuits, allowing for a more informed public and a broader understanding of who comprises that public. If we return to Dewey and Greene's idea of democracy taking place in a community that is always in the making, Ós is an example of a democratic community for the authors it has published and its members. For example, Ós authors grant the organization a license for use of their work, never the copyright, but Ós still asks for permission to use work in

65 Rossich, Albert, "An Overview of Literary Multilingualism”. 
promotional materials that were not originally discussed with the authors. Ós also works to broaden the area of shared concern - literature in Iceland - by consistently publishing new authors in the language of their choice, though this means making typical readers of Icelandic literature uncomfortable. In fact, creating discomfort in the mainstream population is one method that Ós uses to wake people up about the reality of being a marginalized member of society.

Looking at event attendance, sales figures, and media coverage, we can see that Ós Pressan has had an impact on the publishing industry in Iceland by members such as Helen Cova and Ewa Marcinek launching their professional careers there. Through the activities of Ós Pressan, many languages have been rendered visible that are not traditionally recognized as a part of the Icelandic literary landscape. Ós Pressan as a project has been received by the media, both abroad and in Iceland. However, participating in literature production is not really visible. The gatekeeping seems to persist in a way. For example, the percentage of months awarded in artist's salaries to immigrants in Iceland has not increased since Ós Pressan was founded. The change is not really visible in the traditional structures of the Icelandic literary scene, but the changes are visible primarily in the grassroots initiatives.

With projects such as Ós Pressan, immigrants in Iceland have the opportunity to publish their work in Iceland. These structures seem, however, to be understood as immigrant structures. This reality is mirrored in the discussions of Ós Pressan in the media which focus primarily on Ós Pressan as made by foreigners for foreigners, which is not necessarily the reality of Ós Pressan. The radical anomaly of multilingual literature ${ }^{66}$ can be seen here as well. While Ós Pressan serves as an addition to the literary scene, the overall understanding of Icelandic literature as homogenous and extending a centuries-long tradition persists in contemporary society, media, and marketing. Societal focus on Ós Pressan's general structures as a foreign-origin non-profit initiative, as opposed to consideration of the press' literary material, limits the possibility to hear the actual narratives and voices of people on, about, or connected to Iceland in different ways.

66 Rossich, Albert, "An Overview of Literary Multilingualism”. 
In the context of literature, we, therefore, see similar developments to discussions about immigrants, where immigrants stated that they felt that they would mostly be invited to discussions etc. when immigrant issues were discussed, rather than being included in discussions on all kinds of different issues in the society in which they live. ${ }^{67}$ Future studies could incorporate a comparative perspective in order to identify similarities and differences in the experiences of migrant writers in Iceland and in the other Nordic countries. Whether Ós Pressan has changed the traditional notion of Icelandic literature is questionable. The newspaper reports about Ós Pressan, particularly in Iceland, primarily employ an othering tone, which emphasizes Ós as being apart from the traditional Icelandic literary scene seems to indicate that ideas of Ós Pressan as the foreign group persist. The reinvention of the category of the mother language, as suggested by Yildiz, ${ }^{68}$ and any reflection on the concept of Icelandic literature seems to be countered by emphasizing Ós members' length of stay in Iceland and their countries of originm, clearly categorizing them as foreigners in Iceland and Ós Pressan as a project for foreigners.

As studies in other countries have shown that artistic and literary projects can influence societal change in different ways, ${ }^{69}$ it would be interesting to conduct additional qualitative research, e.g. among both Icelandic native speakers and immigrants in Iceland to investigate the effects that Ós Pressan has on their understanding of Icelandic literature and their relation to it in more detail. The activities of Ós Pressan to bring additional voices and, for example, publish work in Icelandic as a second language, might have long-term effects in perspectives on Icelandic as language that can also be spoken with an accent. The fact that Ós Pressan has in its fourth issue published pieces in Icelandic written by a non-native speaker might be seen as an indication in this direction.

Hélène Cixous wrote in The Laugh of the Medusa: "Censor the body and you censor breath and speech at the same time. Write yourself.

\footnotetext{
67 Skaptadóttir, Unnur Dís, Loftsdóttir, Kristín, Konur af Erlendum Uppruna. Hvað Kreppir að?

68 Yildiz, Yazemin, "Beyond the Mothertongue".

69 See Otte, Hanka, "Bonding or Bridging?" and Jeffery et al., "Creative Engagement with Migration”, pp. 3-17. doi: 10.1386/cjmc.10.1.3_1.
} 
Your body must be heard." ${ }^{70}$ For Ós, the body that others censor, the body that must be written and heard, is that of all who are kept out of Icelandic literature by the gatekeepers, artefacts of a patriarchal and traditional nationalistic understanding of what makes Icelandic literature Icelandic.

70 Cixous, Hélène, "The Laugh of the Medusa", Journal of Women in Culture and Society 4/1976, pp. 875-894. https://www.jstor.org/stable/3173239?seq=5\#metadata_info_tab_contents [accessed April 28, 2020], here p. 880. 


\section{Skrifað á mörgum málum: Viðtökur Ós Pressunnar og meðlima hennar á Íslandi og erlendis}

Ós Pressan varð til í íslensku bókmenntasenunni árið 2015 í framhaldi fjöltyngdrar ritstofu sem Reykjavík - bókmenntaborg UNESCO og Borgarbókasafn Reykjavíkur stóðu fyrir. Ós Pressan gefur árlega út bókmenntatímarit sem innheldur verk eftir höfunda sem tengjast Íslandi á einn eða annan hátt og stendur fyrir vinnustofum, bókmenntaklúbbi og upplestrum með innlendum og erlendum höfundum. Í pessari ritgerð verður bókmenntafélagið, sem rekið er án ágóða, tekið sem dæmi um fjöltyngdar bókmenntir og fjallað um viðtökur pess í fjölmiðlum á Íslandi og erlendis. Við skoðum lýðræðisferlið að baki Ós Pressunni og viðtökur sem framtakið og meðlimir pess hafa fengið í fjölmiðlum og í útgáfu á Íslandi. Niðurstaða okkar er að pó að ÓS Pressunni hafi verið vel tekið og sumir meðlima hennar hafi getað hafið feril í bókmenntageiranum, pá hafi íslenskir fjölmiðlar oft stimplað Ós Pressuna sem „hina“, p.e.a.s. með pví að leggja áherslu á erlendan uppruna meðlimanna og hversu lengi peir dveldust á Íslandi. Pessi ímynd Ós pressunnar, að hún standi einhvern veginn utan við íslenskar bókmenntir en sé ekki hluti af peim, sýnir eina ferðina enn pær áskoranir sem peir höfundar, sem tala ekki íslensku sem fyrsta mál, mæta í bókmenntaheiminum á Íslandi.

Lykilorł: fjöltyngdar bókmenntir, innflytjendabókmenntir, frumkvöðlastörf án hagnaðar, lýðræði, útgáfugeirinn, útgáfufélag 
ABSTRACT

\section{Multilingual Writing in Iceland: The Reception of Ós Pressan and its Members Nationally and Internationally}

Ós Pressan was born in the Icelandic literary landscape of 2015 as a continuation of a multilingual writing workshop sponsored by UNESCO Reykjavík City of Literature and the Reykjavík City Library. Ós Pressan prints an annual literary magazine that includes works from authors on, about or connected to Iceland and has organized workshops, a book club, and readings with visiting and local authors. This paper presents the literary collective and publishing nonprofit as an example of multilingual literature. We look at the democratic processes of running Ós Pressan and the reception of the initiative and its members in the Icelandic media and publishing industry and abroad. We conclude that, while Ós Pressan has been received positively and some of its members were able to launch their professional careers in literature, the Icelandic media often frame Ós Pressan as the other by, among other things, emphasizing the members' countries of origin and lengths of stay in Iceland. This image of Ós Pressan as apart from or not a part of Icelandic literature demonstrates once more the challenges authors who don't speak Icelandic as their first language face in the Icelandic literary landscape.

Keywords: Multilingual literature, migrant literature, non-profit initiatives, democracy, publishing industry, literary collective 


\section{REFERENCES}

Ahmed, Sarah, Living a Feminist Life, Durham: Duke University Press, 2017.

Allen, Stuart, "Journalism and the Culture of Othering", Brazilian Journalism Research, 2/2010, doi: 10.25200/BJR.v10n2.2014.776.

Beckett, Rex, "Polishing Iceland: The Reykjavík Ensemble Brings The Polish Experience To The Stage", The Reykjavík Grapevine, 2020, https:/grapevine.is/ icelandic-culture/2020/03/09/polishing-iceland-the-reykjavik-ensemble-bringsthe-polish-experience-to-the-stage [accessed 28 April, 2020].

Bishop, Claire, Artificial Hells: Participatory Art and the Politics of Spectatorship, London: Verso, 2012.

Bjarnar, Jakob, “Pessi fá listamannalaun árið 2019”, Vísir, 2020, https://www.visir. is/g/2019190119758 [accessed April 29, 2020].

Bjarnar, Jakob, Hilmarsdóttir, Sunna Kristín, "Pessi fá listamannalaun árið 2020”, Vísir, 2020, https://www.visir.is/g/2020200109135 [accessed April 29, 2020].

Blatter, Joachim and Markus Haverland, "Relevance and Refinements of Case Studies”, Designing Case Studies. Berlin: Springer, pp. 1-32, doi: 10.1057/ 9781137016669_1.

Böker, Elisabeth, "The Incredible Success Story of Scandinavian Best Sellers on the German Book Market”, Scandinavian Studies, 4/2019, pp. 582-589, https:// www.muse.jhu.edu/article/738251 [accessed April 29, 2020], here p. 586.

Cova, Helen, 2020, Personal Communication, April 8-9.

Cixous, Hélène, "The Laugh of the Medusa", Journal of Women in Culture and Society 4/1976, pp. 875-894. https://www.jstor.org/stable/3173239?seq=5\#metadata_ info_tab_contents [accessed April 28, 2020].

“Cultural Narratives”, Borgarbókasafnið, 2020, https://borgarbokasafn.is/event/welcome/postponed-cultural-narratives [accessed April 28].

CWILA: Canadian Women in the Literary Arts, https://www.abclc.ca/cwila-canadianwomen-in- the-literary-arts [accessed 28 April, 2020].

Daðason, Kolbeinn Tumi, "Pessi fá listamannalaun árið 2018”, Vísir, 2020, https:// www.visir.is/g/2018180109405 [accessed April 29, 2020].

Damery, Shannon, Mescoli, Elsa, "Harnessing Visibility and Invisibility through Arts Practices: Ethnographic Case Studies with Migrant Performers in Belgium”, Arts, 8/2019, pp. 1-17. doi: 10.3390/arts8020049.

Daðason, Kolbeinn Tumi, Pessi fá listamannalaun árið 2018, 2018, https://www. visir.is/g/2018180109405.

Denzin, Norman. K, The Research Act: A Theoretical Introduction to Sociological Methods, Upper Saddle River, NJ: Prentice Hall, 1989.

Dewey, John, Democracy and Education, Holywood, FL: Simon \& Brown, 2012 [1916].

Einarsdóttir, Júlía Margrét, "Skrímsli kennir börnum kosti einverunnar", $R U ́ V$, 2019, https://www.ruv.is/frett/skrimsli-kennir-bornum-kosti-einverunnar [accessed April 28, 2020].

Félag Íslenkra Bókaútgefenda, List of Members, 2018, https:/fibut.is/english/list-ofmembers [accessed April 28, 2020]. 
Flóra útgáfa, 2018, https://flora-utgafa.is/um-okkur [accessed 16.10.2020].

Foster, Clarise, "An Interview with Ós Pressan Collective Members: a rawlings, Randy Stebbins, Anna Valdís Kró, Beatriz Portugal, Ewa Marcinek, Virginia Gillard and Elena Ilkova”. CV2: The Canadian Journal of Poetry and Critical Writing, 40/2017, pp. 21-35.

Forlagid, TMM 3. hefti 2016 https:/www.forlagid.is/baekur/timarit-mm-3-hefti-2016/ ?fbclid=IwAR1m7peEkqq6Ts58wiCuXsa-Ja8fnf4XM4dXyCLl4E6sOueYN26b6ocjKPY [accessed October 16, 2020].

Greene, Maxine, "Diversity and Inclusion: Toward a Curriculum for Human Beings", Teachers College Record, 2/1995, pp. 211-221.

Guðjónsson, Kristján, "Fjölmála skáldasamfélag”, 2016, https:/www.dv.is/fokus/ menning/2016/05/07/fjolmala-skaldasamfelag [accessed 30.04.2020].

Hagstofa Íslands, 2020, https://www.hagstofa.is/utgafur/lysigogn/lysigogn/ ?fileId=19525 [accessed October 16, 2020].

Haraway, Donna, "Situated Knowledges: The Science Question in Feminism and the Privilege of Partial Perspective", Feminist Studies, 3/1988, pp. 575-599. doi:10.2307/3178066.

Hilmarsson-Dunn, Amanda, "Protectionist Language Policies in the Face of the Forces of English", The Case of Iceland. Language Policy, 5/2006, pp. 295-314. doi: 10.1007/s10993-006-9027-2.

Hilmarsson-Dunn, Amanda, Kristinsson, Ari Páll, “The Language Situation in Iceland”, Current Issues in Language Planning, 11/2010, pp. 207-276. doi: 10.1080/14664208.2010.538008.

Hodgetts, Darrin and Kerry Chamberlain, "Analysing News Media", The SAGE Handbook of Qualitative Data Analysis, pp. 380-393. London: SAGE Publications Ltd, 2014. doi: 10.4135/9781446282243.

Hólmarsdóttir, Halla, "Icelandic: A Lesser-Used Language in the Global Community”, International Review of Education, 3-4/ 2001, pp. 379-394, https:// www.jstor.org/stable/3445351?seq=1 [accessed April 28, 2020], here p. 391.

Gunnarsdóttir, Gunnpóra, "Nýjar Raddir Skálda”, Vísir, 2015, https://www.visir. is/g/2015707259997 [accessed 30.04.2020].

Griest, Stephanie Elizondo, “The Quest to Keep Iceland's Language Alive”, airbnbmagazine, 2018, https://medium.com/airbnbmag/the-quest-to-keep-icelandslanguage-alive-b22d4b6d74f2 [accessed April 30, 2020].

"Immigrants and Persons with Foreign Background 2019", Statistics Iceland, 2019, https://statice.is/publications/news-archive/inhabitants/immigrants-and-persons-with-foreign-background-8903 [accessed April 29, 2020].

International Review of Education, 3-4/ 2001, pp. 379-394. https://www.jstor.org/ stable/3445351?seq=1 [accessed April 28, 2020].

Jeffery, Laura, Palladino, Mariangela, Rotter, Rebecca, Woolley, Agnes, "Creative Engagement with Migration”, Crossings: Journal of Migration E Culture, 10/2019, pp. 3-17. doi: 10.1386/cjmc.10.1.3_1.

Jónsson, Jakob S., „Kvenleg reynsla, ósvikin kómík. Leiklistargagnrýnandi Kjarnans fjallar um sýningu Reykjavik Ensemble, Polishing Iceland”, Kjarninn, 2020, https://kjarninn.is/folk/2020-03-20-kvenleg-reynsla-osvikin-komik 
[accessed 30 April, 2020].

Kristinsson, Ari Páll, "National Language Policy and Planning in Iceland - Aims and Institutional Activities", National Language Institutions and National Languages. Contributions to the EFNIL Conference 2017 in Mannheim, ed. Gerhard Stickel, Budapest: Research Institute for Linguistics, Hungarian Academy of Sciences, 2018, pp. 243-249.

"Lesum Heiminn / Read the World", Bókmenntaborgin, 2018, https://bokmenntaborgin.is/lesum-heiminn [accessed 28 April 2020].

Marling, William, Gatekeepers: The Emergence of World Literature and the 1960s, Oxford: Oxford University Press, 2016, doi: 10.1093/acprof:oso/9780190274146.001.0001. Marcinek, Ewa, “Ísland pólerað”, Tímarít Máls og Menningar, 2016.

Minnich, Elizabeth Kamarck, "Philosophy, Education, and the American Tradition of Aspirational Democracy", Feminist interpretations of John Dewey, ed. Charlene Haddock Seigfried, University Park, PA: The Pennsylvania State University Press, 2002, pp. 95-112.

Olgeirsson, Birgir, "Pessi fá listamannalaun árið 2017”, Vísir, 2020, https://www. visir.is/g/2017170109223 [accessed April 29, 2020].

Otte, Hanka, "Bonding or Bridging? On Art Participation and Social Cohesion in a Rural Region of the Netherlands", Poetics, 2019, doi: 10.1016/j.poetic.2019.02.006.

Parks, Tim, "The Dull Global Novel”, Where I'm Reading From: The Changing World of Books, Tim Parks, New York: New York Review Books, 2015, pp. 25-28.

Putnam, Robert, Bowling Alone: The Collapse and Revival of American Community, New York: Simon \& Schuster, 2000.

Reykjavík UNESCO City of Literature: About Us https://bokmenntaborgin.is/en/ about-us/city-of -literature-and-literature [accessed April 28, 2020].

Reykjavík UNESCO City of Literature, https://bokmenntaborgin.is/en [accessed October 16, 2020].

Rithöfundasamband Íslands, Félagatal, 2020, https://rsi.is/felagatal [accessed April 29, 2020].

Rise, "10 things you need to consider if you are an artist not of the refugee and asylum seeker community looking to work with our community”, Rise, Refugees, Survivors and Ex-detainees, http://riserefugee.org/10-things-you-need-toconsider-if-you-are-an-artist-not-of-the-refugee-and-asylum-seeker-community-looking-to-work-with-our-community [accessed April 30, 2020].

Rossich, Albert, "An Overview of Literary Multilingualism", Comparative Critical Studies, 1/2018, pp. 47-67, doi: 10.3366/ccs.2018.0259.

RÚV. Lestin - Íslenska með hreim, Emilíana Torrini og bókasöfn. https://www.ruv. is/utvarp/spila/lestin/ 23619/7hr8me?fbclid= IwAR1iUgh6_zsOo 7JqvXc JLxoELjtzgrh2J1sRo94PZY47GOl7rnzUDsyJteA [accessed 16.10.2020].

Sigurðardóttir, Jórunn, “Íslenskar bókmenntir, hvað er pað?”, RÚV, 2018, https:// www.ruv.is/frett/islenskar-bokmenntir-hvad-er-thad [accessed Apri 28, 2020].

Sigurðardóttir, Jórunn, "Ljóð og sögur á ólíkum tungumálum”, RÚV, 2019, https:// www.ruv.is/frett/ljod-og-sogur-a-olikum-tungumalum [accessed April 30, 2020]. 
Skaptadóttir, Unnur, Innes, Pamela, "Immigrant Experiences of Learning Icelandic and Connecting with the Speaking Community", Nordic Journal of Migration Research, 1/2017, pp. 20-27.

Skaptadóttir, Unnur Dís, Loftsdóttir, Kristín, Konur af Erlendum Uppruna. Hvað Kreppir að?, Skýrsla unnin fyrir félagsmálaráduneytið, Reykjavík: Háskóli Íslands, 2020.

Smith, Dorothy, "A Peculiar Eclipsing: Women's Exclusion from Man's Culture", Women's Studies International Quarterly, 4/1978, pp. 281-296.

"Snúlla finnst gott að vera einn / Upplestur og perl", Akureyrarbor, https://www. akureyri.is/ grimsey/moya/calendar/snulla-finnst-gott-ad-vera-einn-upplesturOg-perl, 2019 [accessed April 28, 2020].

Spender, D, "The Gatekeepers: A Feminist Critique of Academic Publishing", Doing Feminist Research, ed. Helen Roberts, London: Routledge, 1981, pp. 186-202.

Svartalogn, Pjóðleikhúsið, 2018, https://www.leikhusid.is/syningar/svartalogn [accessed April 28, 2020].

“Sögur-Snúlla finnst gott að vera einn”, Útvarp KrakkaRÚV, 2019, https://player. $\mathrm{fm} / \mathrm{series} / \mathrm{utvarp}-\mathrm{krakkaruv} / \mathrm{sogur}$-snulla-finnst-gott-ad-vera-einn [accessed April 28, 2020].

Valdis Kro, Anna, Hoffmann, Lara, “Ós Pressan”, 2019, Multilingual Month, https:/ multilingualmonth.org/2019/03/18/os-pressan-2/ [accessed April 28, 2020].

Van Schalkwyk, Jo “Grein með hreim”, Flóra útgáfa, 2018, https://flora-utgafa. is/2utgafa/grein-med-hreim [accessed 16.10.2020].

VIDA: Women in Literary Arts. About the VIDA Count, https://www.vidaweb.org/thecount [accessed April 28, 2020].

Yildiz, Yazemin, Beyond the Mothertongue. The Postmonoligual Condition, New York: Fordham University Press, 2012.

Yin, Robert K., Case Study Research Design and Methods, Thousand Oaks, CA: Sage, 2014 [1984].

"Pýðingar", Bókmenntaborgin, 2019, https://bokmenntaborgin.is/borgin/frettir/thydingar [accessed April 28, 2020]. 